\title{
Nigeria and United States Prisons: A comparative Analysis of Mass Overcrowding
}

\section{Gabriel A*}

Faculty of Law, Criminology with Forensic Psychology, Middlesex University, London, UK

*Corresponding Author: Akinyemi Gabriel, Faculty of Law, Criminology with Forensic Psychology, Middlesex University, London, UK, Tel: +2348124074453; E-mail: gabrieloluseyi_akinyemi@yahoo.co.uk

Received date: January 05, 2018, Accepted date: January 17, 2018, Published date: January 22, 2018

Copyright: ( 2018 Gabriel A. This is an open-access article distributed under the terms of the Creative Commons Attribution License, which permits unrestricted use, distribution, and reproduction in any medium, provided the original author and source are credited.

\begin{abstract}
The goal of the prison system in both Nigeria and United States prison is to restore an offender to the society after "doing time" and make him useful and productive in the community. The specific goal is re-integration. Since both country's correctional institutions have the same objective, this dissertation will take a critical look of some weaknesses and strengths of both systems and proffer some recommendations for further study and development. Generally, in this comparative analysis, this dissertation would be comparing the same things in both countries throughout although this is of course can be difficult as the information may not be available - but this dissertation will work within the available information and data. This dissertation is an offshoot of a research carried out in Nigeria prisons in October 2012. Overcrowding is a thorn in the flesh bedeviling both Nigeria and United State' prisons; most of the prison cells are not suitable for human inhabitance; hygienic situations are pitiable; occupational, skill acquisition, educational opportunities and reformation exist on paper. There is a high recidivist statistics of inmates who relapse into crime after their release from the correctional facilities, various NonGovernmental Organizations (NGO) and pressure groups have called on the Government to reform the prison system in Nigeria but all measures geared towards this has defied an acceptable solution. In the America systems, there is high recidivism just like what is obtained in Nigeria, the prison system is in a crisis and various commissions has called for a total overhaul of the system.
\end{abstract}

The criminal justice system in Nigeria and America enforce the law through the court. The judge or the jury has the constitutional power to pass judgment on accused either by the use of community service; probation or fine; jailterm or decide to combine all the punishments within the confines of the law. Therefore, this dissertation will do a critical comparative analysis between Nigeria and United States prison with its focus on mass overcrowding, to find out the causes and the consequences of the problem.

Like the America correctional institutions, Nigeria prisons are rated as maximum and minimum security facilities. While the Nigerian prisons are relatively old, most of the correctional facilities were not designed for the purpose for which they are being used. In Nigeria as in the United States, Parkinson's Law applies to prison construction; prison populations grow to fill expanding capacity, this growth has led to mass overcrowding and "survival of the fittest".

Keywords: Prison; Crime; Punishing offenders; Incarceration

\section{Introduction}

According to Clear, he debates that for forty years, the United States has committed themselves to mass incarceration to solve its crime problem [1]. Clear labels this "penal harm movement" which advocates helplessness and other stringent measures aimed at punishing offenders. Treatment and rehabilitation of offenders were incorporated in the 20th century and has been one of the main crime control strategies utilized in the United States, with the hopes of both incapacitating offenders and deterring current and future offenders.

As Garland argues; "Unlike the past, prisons are not seen as a last resort and a place where offenders are exposed to treatment. Rather, prisons are now used for a variety of offenders, both serious and minor, where the goal is to deter future offenders, incapacitate current criminals, and, at times, exact revenge on those found guilty of crimes" $[2,3]$.
The overarching consequence of these is that correctional facilities are filled with hardened and violent criminals. The penal harm movement which fosters incarceration has led to more people currently behind bars than working at both McDonald's and Wal-Mart combined worldwide. This has led to 600 percent increase since 1972.

According to Beckett and Gest; "Mass imprisonment of the late 1990s can be traced to two basic shifts in politics and economics. The growth of harsh sentencing policies and a punitive approach to drug control began with a rightward shift in American politics, first visible at the national level in the mid-1960s. Barry Goldwater's ill-fated presidential run in 1964 was pivotal" [4,5].

The World Prison Brief believes that the America houses about 2.4 million inmates making them the number one incarcerator in the world [6]. Consequently, the United States has the highest population of inmates behind bars in the world. The reliance on mass imprisonment to address the crime problem is not only an American phenomenon, Nigeria has also borrowed a leaf from it and mass incarceration has relatively soared high since the 1990'S. Although, there have been some high rate of incarceration in some other 
Page 2 of 6

European countries, but this is a "drop in the ocean" when compared to the United States.

World Prison Brief says that America imprisons roughly 750,000 more individuals than China and roughly 1.5 million more than Russia, the world's second largest incarcerator. According to Hartney, when collating data of incarceration statistics around the world, the United States still leads the world with 760 inmates per 100,000 people, next in line is Russia with a rate of 620 people incarcerated per 100,000. In collating data statistics in Europe countries, Czech Republic leads with a statistics of 210, followed by Spain with a statistics of 164, and England and Wales with a statistics of 154 [7]. All these figures are less than one third of the statistics collated in America. In comparing America to its North American neighbors, the margin is phenomenal. The United States' has a statistics of compared to 116 found in Canada and 208 in Mexico. According to Warren one in four people incarcerated in the world is locked up in the United States prison [8].

Tonry further states that China is four times bigger than America, but houses 14 percent of the world's incarcerated population while the United States houses 25 percent of over 9 million people incarcerated worldwide. He further debates that United States drive has been geared towards mass incarceration as the years pass by, thereby resulting to a state of emergency; consequently the correctional facilities are grappling with mass overcrowding [9].

.According to Lappi-Seppala, countries like Denmark, Norway, and Sweden have had stable imprisonment rates between 40-60 prisoners per 100,000 populations for the last half century [10]. Weigend further opines that Germany has also had stable imprisonment rates for the last 25 years hovering around 90 inmates per 100,000 populations [11].

Blumstein and Cohen argue that in the early 20th Century, the United States imprisonment statistics was stable and was around 110 inmates per 100,000 populations from 1930-1970 [12]. They further debate that the stability does not have anything to do with the population growth because during this time, the United States population increased by 50 percent. Therefore, the increase in population did not lead to a boom in prison population. During this period, there was war, the Great Depression, population increases, and increases in the crime rate but the prison population growth was minimal and stable.

Currie and Sabol et al. agrees that prison population instability soon began when the United States engaged in a mass incarceration binge originating in the 1970s [13,14]. In 1971, there were fewer than 200,000 prisoners in the United States. This number has increased in the last 40 years with presently over 1.6 million Inmates in state and federal prison.

Sabol et al. \& World Prison Brief says that when 785,000 people confined in local jails are added to 1.6 million inmates in state and federal prison, there will be 2.4 million inmates spread across America's prisons $[6,14]$. That's a whopping 600 percent increase in the prison population since the 1970's. Lacey also affirms this by agreeing that America's imprisonment statistics is a thousand times higher than even countries that are plagued with violence and dictators [15]. Roy Walmsley says that prison is the best place to be schooled in criminal activities, incarceration hardens the criminal and makes him worse off while overcrowding is the aftermath [16].

\section{Objectives}

The broad objective of this study is to compare and contrast the prison systems in Nigeria and United States with regards to mass overcrowding in the prisons. The goal of the dissertation is

1) To investigate the causes of mass overcrowding in Nigeria and United States prison system.

2) To investigate the similarities between Nigeria and United States prison system.

3) To investigate the differences between Nigeria and the United States prison system.

4) To tackle mass incarceration headlong in Nigeria and United States prison system.

\section{Methodology}

\section{Research design}

This research examined the conditions in the Nigeria and the United States prison. In Nigeria, Kirikiri maximum prison in Lagos was used as a case study. Fifty inmates of Kirikiri maximum prisons were selected through simple random sampling to partake in the survey. Questionnaires were administered to the inmates to ask series of questions about life behind bars while the staffs of the prison were interviewed orally. While analyzing the data collected for the United State' research, it was done through quantitative and qualitative analysis.

\section{Population and sampling procedure}

The sample population for the survey in Kirikiri maximum Prison in Lagos comprised of five hundred inmates out of which ten percent of the inmates were selected for the survey. In other words the sample size constituted fifty inmates of Kirikiri maximum prisons. The sample size were scattered in more than twenty different cells and inmates were chosen using simple random sampling through balloting method.

\section{Instruments}

The method of data collection for the research in Nigeria comprise of both quantitative and qualitative methods. In the research carried out in Nigeria, when using quantitative data, it involved the use of questionnaires while qualitative data involved oral interview with some selected staffs of the prison that were relevant to the research. A questionnaire that has three different sections was administered to the inmates. The inmates selected for the research were first stratified on the type of offence that led to their incarceration.

Furthermore, the reason oral interview was necessary is because it will helped to ascertain or disprove the information gathered from the inmates by the use of questionnaires. The process involved selecting about four to six respondents who had first-hand knowledge and could give honest information about how the prison is run. These respondents ranged from those in the prison's medical department, the welfare department, the records department, the religious leader and the prison governor. They were all interviewed orally.

The research of the United State' prison made use of both primary and secondary data. This involved the perusal of some official documents and books which gave the researcher more insights about the history of American prisons, how it was established, how it is run, 
Citation: Gabriel A (2018) Nigeria and United States Prisons: A comparative Analysis of Mass Overcrowding. J Foren Psy 3: 129. doi:

Page 3 of 6

and the geographical topography of the prison amongst others. The data analysis used for both comparative analysis comprise of distribution of respondent's socio-demographic characteristics, level of education, religion, marital status and category of offence (Tables 1-6).

\begin{tabular}{|l|l|l|}
\hline Age ( in years) Frequency Percentage & Frequency & Percentage \\
\hline $14-17$ & 9 & 10 \\
\hline $18-29$ & 11 & 12.2 \\
\hline $30-39$ & 12 & 13.3 \\
\hline $40-49$ & 27 & 30 \\
\hline $50-59$ & 23 & 25.6 \\
\hline 60 and above & 8 & 8.9 \\
\hline
\end{tabular}

Table 1: Distribution of respondent's socio-demographic characteristics.

\begin{tabular}{|l|l|l|}
\hline Religion & Frequency & Percentage \\
\hline Christianity & 65 & 72.3 \\
\hline Islam & 20 & 22.2 \\
\hline Traditional & 3 & 3.3 \\
\hline Others & 2 & 2.2 \\
\hline No Response & NIL & NIL \\
\hline
\end{tabular}

Table 2: Distribution of respondent's religious beliefs.

\begin{tabular}{|l|l|l|}
\hline Religion & Frequency & Percentage \\
\hline Christianity & 65 & 72.3 \\
\hline Islam & 20 & 22.2 \\
\hline Traditional & 3 & 3.3 \\
\hline Others & 2 & 2.2 \\
\hline No Response & NIL & NIL \\
\hline Level of Education & Frequency & Percentage \\
\hline No Western Education & 33 & 36.7 \\
\hline Primary Education & 14 & 15.6 \\
\hline Secondary Education & 15 & 16.7 \\
\hline Tertiary Education & 28 & 31.1 \\
\hline
\end{tabular}

Table 3: Distribution of respondent's level of education.

\begin{tabular}{|l|l|l|}
\hline Marital Status & Frequency & Percentage \\
\hline Married & 28 & 31.1 \\
\hline Single & 50 & 55.6 \\
\hline Divorce/Separated & 4 & 4.4 \\
\hline Widow/Widower & 8 & 8.9 \\
\hline
\end{tabular}

\begin{tabular}{|l|l|l|}
\hline No Response & NIL & NIL \\
\hline
\end{tabular}

Table 4: Distribution of respondent's marital status.

\begin{tabular}{|l|l|l|}
\hline Family Background & Frequency & Percentage \\
\hline Poor & 35 & 38.9 \\
\hline Very Poor & 49 & 54.5 \\
\hline Rich & 4 & 4.4 \\
\hline Very Rich & NIL & NIL \\
\hline No Response & 2 & 2.2 \\
\hline
\end{tabular}

Table 5: Distribution of respondent's family background.

\begin{tabular}{|l|l|l|}
\hline Offence Category & Frequency & Percentage \\
\hline Armed Robbery & 38 & 42.2 \\
\hline Murder/Manslaughter & 40 & 44.4 \\
\hline Kidnapping & 2 & 2.2 \\
\hline Burglary & 1 & 1.1 \\
\hline Advance fee fraud & 3 & 3.3 \\
\hline Rape & 4 & 4.4 \\
\hline Drug trafficking & 1 & 1.1 \\
\hline Others & 1 & 1.1 \\
\hline No response & NIL & NIL \\
\hline Total & 90 & 100 \\
\hline
\end{tabular}

Table 6: Distribution of respondent's offence category.

\section{Research time-table and resources}

The time plan of the research is from July till October 102014 spanning three months and a few weeks. The research also made use of prison documents and books, journals and articles from libraries and internet materials to further complement the research surveys. Academic resources and academic journals too were critically examined in the research work.

\section{Literature Review}

It is necessary to have an understanding of the theories of incarceration and how it affects overcrowding in the prisons.

\section{Deterrence theory}

According to Garland for thirty years now, America has been tough on criminals in other to make crime less appealing to any potential offender [2,3]. According to Oluwakuyide; "Incarceration is a tool used in Nigeria to punish offenders" [17].

In both countries, Garland speaking concerning the United States and Oluwakuyide speaking concerning Nigeria both agree that a criminal is a rational human being that weighs the cost and benefits of crime. 
Beccaria, a scholar of the classical school of criminology, a deterrence theorist says that "People seek out situations that bring them pleasure while avoiding those that cause them pain"

Becker believes that; "If the costs of crime-in this case, incarceration-outweigh the benefits, a rational person will choose to not commit the crime; however, if the potential rewards of the crime outweigh the costs, the criminal act will be pursued" [18].

Nagin et al. argues that deterrence theorists are also known as "reductionists" because they see the experience of prison as merely a based on cost-benefit perspectives because they argue that offenders simply weigh the pros and cons of crime before deciding whether to commit crime or not therefore prison to the offenders is not a social experience [19]. Deterrence theorists' major argument is, if the costs of committing a crime outweigh the benefits to be derived from the crime, and then the criminal will be deterred from engaging in crime.

In view of this, deterrence theorists propose that there should be stringent punitive measures and sanctions that will cause the offender pain. The sanction must outweigh the benefits of the crime committed by the offender. Therefore once the sanction is tough and punitive, the criminal will desist from criminal behavior. This school of thought also debates that long or maximum prison sentence should be imposed as another means of deterrence to criminals.

Currie disagrees with this school of thought; he believes the "get tough" movement has not achieved its goal by reducing crime; instead it has led to mass incarceration or overcrowding in the prisons. There are two types of deterrence; we have the general and specific [13].

The goal of the general deterrence is to make crime unattractive to the public by punishing specific deviants. By punishing specific deviants, it is to pass a message across to the public that they would be dealt with the same way if the commit a criminal act. When specific deviants are incarcerated, the goal is to send a strong message to the public that the cost of crime far exceeds the benefits one stands to gain there. It is intended to stop those who haven't been caught committing crime and those who are contemplating about committing crime.

The goal of specific deterrence is to deter the criminal from future crime and not the public unlike general deterrence. The punishment is harsh; the cost is calculated to outweigh the benefits of the crime. Deterrence theorists argue that criminals who are given prison sentences compared to those given non-custodial sentences will be more deterred from crime. Sadly this has led to mass incarceration in the prisons; the Prison is viewed as being punitive because offenders are removed from society, they lose communication with family and friends, and placed in an unattractive environment. Furthermore, deterrence theorists' debates that criminals who are incarcerated for longer periods of time behind bars as against those who get less time will be less likely to reoffend once released. The logic here is that since the prison environment is harsh, it will serve as deterrence to the criminal especially when he spends a longer time in such punitive environment and he will be less likely to re-offend once he is out.

As evidenced by the high re-offending rate in both countries, the idea that imprisonment is a specific deterrent is debatable. In fact, specific deterrence has led to prison population explosion in Nigeria and the United States.

\section{Age-graded social bond theory}

The age-graded social bond theory's proponent is Sampson and Laub [20]. This theory dwells on the social bond of criminals for example their work or marriage which will make the criminal abstain from crime regardless of the characteristics of his upbringing and risk factors he has been exposed to due to pressure these social bonds exert. Nevertheless, when these criminals are cut off from these bonds, then they are under pressure to commit crime. For example, incarceration severe ties between an individual and his work or marriage, once this happens, the criminal is "free" to commit crime.

Sampson and Laub's empirical theory is an offshoot of Sheldon and Eleanor Glueck's study. After some thorough empirical studies using database of juvenile delinquents and non-delinquents, they concluded that when a juvenile is incarcerated, it will affect his work and marriage negatively and lead to future criminal behavior. This theory has also shed more light on one of the causes of population boom in the prisons especially in respect to Nigeria and United States which this dissertation is addressing.

\section{General strain theory/coercion theory}

Merton's work was developed by Agnew and he propounded the general strain theory [21-23]. Agnew states that; "When individuals can't attain their goals in life, they experience strain and a corresponding pressure to alleviate the strain due to the negative effects. As a way to ease or escape this strain and negative affective state, individuals often resort to criminal behavior."

Furthermore, Agnew declares that; "When strains are seen as unjust, high in magnitude, associated with low social control, and create pressures or incentives to engage in crime, they are very likely to lead to a criminal coping response"

Colvin developed the coercion theory from the works of Agnew [24]. He explains that there is a correlation between coercion and crime which is most likely triggered off by anger, -weak restraining power, the abating social bonds, and forcible environs.

Colvin debates that the degree of coercion exercised, the persistency of the coercion and how the coercion is used will determine the criminal behavior of individuals. For example, the prison is a coercive environment that controls inmates, strips them of their "rights", victimize them for many days, weeks, months or years as the case may be with no relief in sight. This will lead to strains that will create an avenue for inmates to be hardened the more and also encourage future criminal behavior when released. Basically, both theories are saying that the prison is an environment that encourages criminal coping response that will birth future criminal behavior due to anger and frustration of the inmates in such environment.

Policymakers in the United States have debated that keeping offenders together can be disadvantageous. The Auburn and the Pennsylvania prison systems were created to regulate communication between and among inmates in order for them not to influence one another negatively. During the Auburn prison System, inmates worked in groups without verbal communication during the day and were confined in solitary cells at night. Conversely, the Pennsylvania prison System separated the inmates day and night and were not allowed to see or communicate with each other. All these were done to break criminal tendencies among the inmates.

\section{Labeling theory}

Cole in labeling theory contends that when the system sanctions an individual publicly for committing crime, this can ultimately lead have unintended of more crime [25]. Schneider corroborates this argument 
by decrying naming, shaming and sanctioning criminals publicly in other to have a deterrent effect; he concluded that instead of having a deterrent effect, it's going to skyrocket the problem it is trying to deal with [26].

Braithwaite further lends his voice by saying; "This public sanctioning, particularly when done in a stigmatizing manner and the treatment of a person as a criminal result in the internalization of a criminal self-concept within the individual" [4].

Merton further stipulates that; "Offenders who have this criminal self-conception often fall victim to a self-fulfilling prophecy where they act in accordance to their new criminal identity" [21].

Therefore, offenders begin to see themselves as criminals and begin to act as one. The negative consequence is that the society labels the offender as a "criminal." When others discover that this individual has been labeled, they begin to treat the individual with scorn either by rejection or seeing the individual as unscrupulous. The identity of this individual is completely lost due to this labeling. It will in turn affect the offenders' relationship either with family or friends. As a way out, the criminal is attracted to other individuals who have been labeled thereby leading to more criminal behavior and over population of the prisons. The society often regards prisoners as hardened and dangerous; therefore the label attached to ex-convicts is a particularly stigmatizing and damaging one [27-30].

Furthermore, the prison environment strips the offenders of their freedom, they are punished severely and everything about the prison reminds them of their identity as criminals.

Dealing with similar hardships, these offenders associate with one another and further reinforce each other's criminal self-conceptions, resulting in the continuance of the offenders' criminal behavior. After an offender is set free from the correctional facility, he has to contend with the stigma of being labeled an "ex-convict".

To further compound the offender's woes, Manza and Uggen argue that; "In America, criminals lose voting privileges after a felony conviction, and this is a reality for over five million individuals, with blacks especially affected" [31].

Even though not being able to vote may not be a limitation for exconvicts, Manza and Uggen further debates that since civic duty is one of the ways an individual relates with the community as a source of identity, when the individual is disenfranchised it can lead to low selfesteem and a disconnect between the ex-convict and the society thereby leading to more criminal behavior. In conclusion, the cycle of incarceration starts all over again therefore reducing population of inmates in the prisons may be a wild goose chase. As lawmakers promote more "get tough policies" that keeps inmates behind bars in punitive environments, it is necessary to find out what the consequences of this reliance on prison in Nigeria and the United States is having on the subsequent criminal behavior of inmates which subsequently leads to recidivism and the end result is mass overcrowding in the prisons [32-36].

\section{Summary}

There are lots of key differences between the way the criminal justice system and the prison is operated in Nigeria and America but one notable significant difference is the factor that contributes to mass overcrowding in the both prison system. In the United States, according to Amnesty International, the jailbirds spread across
America's correctional facilities are well fed and housed but mass overcrowding is a prominent feature due to relentless sentencing and punishment of any harmful behavior and traits exhibited by the inmates, another factor that contributes to overcrowding is recidivism which is also known as re-offending [37-38].

In Nigeria, Amnesty International argues that the use of holding charges is archaic and tramples on the fundamental human right of the suspect $[39,40]$. Torture is used to extract confessional statements from suspects across police cells, most of the prisons across Nigeria are dilapidated and also full of awaiting trial inmates whose cases drag for years in the court of law due to several factors like adjournments, perpetual strikes by the member of the bench, loss of case file, waiting for director of public prosecutions (DPP) advise on the case and lack of court's jurisdiction to entertain the case [21,41-43].

For example, a suspect who is accused of theft, who should normally spend between two to three years behind bar if he is found guilty can have fall a victim to any of this malady mentioned. This suspect will become an awaiting trial inmate, may spend up to ten years awaiting his trial or in some cases two decades behind bars, when the court of law finally decides to entertain his case and finds him guilty, he is summarily discharged and acquitted without compensation [44-48].

This according to Amnesty International is some of the injustice that characterizes life in Nigeria prisons and the consequence is mass overcrowding. Nigerian police also compounds to this problem by sending suspects of capital offences such as murder to the magistrate court even when they know the magistrate court doesn't have the legal powers to entertain such cases. They do this to get a remand so they can probably keep the suspects locked away forever. Magistrate Courts usually remand suspects in prison custody pending the conclusion of police investigation which may drag for years. The police use these as an avenue to torture suspects to confess to crimes they may not have committed. Amnesty international has also accused the Nigeria police of summarily executing suspects in their custody to make way for new and fresh suspects who they can torture and extort $[49,50]$.

\section{Conclusion}

In Nigeria and the United states, incarceration is the main sanction used against individuals who are suspected of breaching criminal law or those who are convicted of such breaches. The over-dependence on prisons leads to a series of mutually reinforcing challenges in responding appropriately to the social reintegration needs of offenders, while violating the rights of those who are innocent.

\section{References}

1. Clear TR (1994) Harm in american penology: Offenders, victims, and their communities. New York: SUNY press.

2. Garland D (2001) The culture of control: Crime and social order in contemporary society. Chicago: University of chicago press.

3. Garland D (2001) Introduction: The meaning of mass imprisonment. In Mass imprisonment: Social causes and consequences, ed. David Barland : 1-3.

4. Braithwaite J (1989) Crime, shame and re-integration. Cambridge, UK: Cambridge university press.

5. Ted G (2001) Crime and politics: Big government's erratic campaign for law and order. New York: Oxford university press.

6. World Prison Brief (2009) London: King's college London, international centre for prison studies. 
7. Hartney C (2006) U.S. rates of incarceration: A global perspective. Oakland, CA: National council on crime and delinquency.

8. Warren J (2008) One in 100: Behind bars in America. Washington, DC The pew charitable trusts.

9. Tonry M (2007) Determinants of penal policies. Chicago: University of Chicago Press.

10. Lappi-Seppala T (2007) Penal policies in Scandinavia. Chicago: University of chicago press.

11. Weigend T (2001) Sentencing and punishment in Germany. New York Oxford university press.

12. Blumstein A, Cohen J (1973) A theory of the stability of punishment. J Crim Law Criminol 64: 198-2.

13. Currie E (1998) Crime and punishment in America. New York: Metropolitan books.

14. Sabol WJ, West HC, Cooper M (2009) Prisoners in 2008. Washington, DC: Bureau of justice statistics.

15. Lacey N (2010) The prisoners dilemma: Political economy and punishment in contemporary democracies. Cambridge: Cambridge University Press.

16. Walmsley R (2003) Development and Statistics Directorate. World Prison Population List: fourth edition. Findings No. 188.

17. Oluwakuyide A (2001) Reforming our prisons. The Nigerian Tribune, 4th December 2001

18. Becker GS (1968) Crime and punishment: An economic approach. J Political Econ 76: 169-217.

19. Nagin DS, Cullen FT, Jonson CL (2009) Imprisonment and reoffending. Chicago: University of Chicago Press.

20. Sampson RJ, Laub JH (1993) Crime in the making: Pathways and turning points through life. Cambridge, MA: Harvard University Press.

21. Merton RK (1968) Social theory and social structure. New York: The Free Press.

22. Agnew RS (1992) Foundation for a general strain theory of crime and delinquency. Criminol 30: 47-87.

23. Agnew RS (2006) Pressured into crime: An overview of general strain theory. Los Angeles: Roxbury press.

24. Colvin M (2000) Crime and coercion: An integrated theory of chronic criminality. New York: St. martin's press.

25. Cole S (1975) The growth of scientific knowledge: Theories of deviance as a case study. New York: Harcourt Brace Jovanovich.

26. Schneider L (1975) Ironic perspective and sociological thought. New York: Harcourt, Brace and Jobanovich.

27. Abramsky S (2002) Hard time blues: How politics built a prison nation. New York: Thomas dunne.

28. Adetula GA, Adetula A, Fatusin AF (2010). The prison subsystem culture its attitudinal effects on operatives convicts and the free society. Ife Psychology 18: 232-251.

29. Agomoh UR (1996) decongesting the nigerian prisons and the police cells: A handbook of practical strategies for remand population. Lagos: PRAWA.
30. Austin J, Irwin J (2001) It's about time: America's imprisonment binge, 3rd ed. Belmont, CA: Wadsworth.

31. Manza J, Uggen C (2006) Locked out: Felon disenfranchisement and American democracy. New York: Oxford university press.

32. Awolowo O (1985) Adventure in power: My march through prison: Ibadan: Macmillan publishers.

33. Bonczar T (2003) Prevalence of imprisonment in the U.S. population, 1974-2001. Washington, DC: Bureau of justice statistics.

34. Chen MK, Shapiro JM (2007) Do harsher prison conditions reduce recidivism? A discontinuity-based approach. Am Law Eco Review 9: 1-29.

35. Fellner J, Mauer M (1998) Losing the vote: The impact of felony disenfranchisement laws in the united states. Washington, DC: The sentencing project.

36. Gendreau P, Goggin C, Cullen FT, Andrews DA (2000) The effects of community sanctions and incarceration on recidivism. Forum on Corrections Research 12: 10-13.

37. Amnesty International (2008) Nigeria: Prisoners' Rights Systematically Flouted. London: Amnesty International AI Index: AFR 44/001/2008.

38. Holzer HJ (2007) Collateral costs: The effects of incarceration on employment and earnings among young men. Madison, WI: Institute for Research on Poverty.

39. Human Rights Watch (2002) Race and incarceration in the united states. New York: Human rights watch.

40. Human Rights Watch (2003) Incarcerated america. New York: Human rights watch.

41. Ifiomu O (1987) Hell on earth: Our prisons and dreaded chambers. Af Concord 147: 14-21.

42. Kangiwa GA (1986) The political economy of crime in sokoto town.

43. Obioha EE (1995) Prison culture in Nigeria: A study of life within agodi prison community.

44. Orakwe IW (2005) Killing the nigerian prisons through prosecution ineptitude. The Reformer 2: 45-48

45. Sabol WJ, Adams WP, Parthasarathy B, Yuan Y (2000) Offenders returning to federal prison, 1986-97. Washington DC: Bureau of justice statistics.

46. Sabol MJ, Lynch JP (2007) Assessing the longer-run consequences of incarceration: Effects on families and unemployment. association for public policy and analysis, new york.

47. Smith P, Goggin C, Gendreau P (2002) The effects of prison sentences and intermediate sanctions on recidivism: general effects and individual differences. Ottawa: Solicitor general canada.

48. Soyinka W (1972) The man died: Prison notes london: Pengium books.

49. Villettaz P, Killias M, Zoder I (2006) The effects of custodial vs. noncustodial sentences on re-offending: A systematic review of the state of knowledge. Philadelphia: Campbell collaboration crime and justice group.

50. Beckett K (1997) Making crime pay: Law and order in contemporary american politics. NewYork: Oxford university press. 